\title{
The Complexity of the Law in Local Government Comparison of Greece and Spain
}

\author{
Despoina Fotiou \\ Department of Political Science and International Relations, University of the Peloponnese, Korithos, Greece
}

Email address:

Despoinafotiou0@gmail.com

To cite this article:

Despoina Fotiou. The Complexity of the Law in Local Government Comparison of Greece and Spain. Journal of Public Policy and Administration. Vol. 5, No. 1, 2021, pp. 8-12. doi: 10.11648/j.jppa.20210501.12

Received: January 6, 2021; Accepted: February 8, 2021; Published: February 23, 2021

\begin{abstract}
This study is part of Phd thesis about the effects of the complexity of the institutional framework on the operation of the local governance in Greece and it will compare the responsibilities of local government in Greece and Spain. More specifically, the different levels of local government will be compared, with a greater focus on the municipalities, in order to capture the differences and similarities that exist between the two countries. In addition, the research will examine the degree of complexity of responsibilities as well as the areas in which they extend. Based on the legislative and institutional framework of both countries, responsibilities will be compared in areas such as local development, social policy, education, etc. The content of local government is the administration of local affairs according to the needs of local communities, in these article we study the way this local government designs its structure and way of working for this purpose.
\end{abstract}

Keywords: Local, Government, Authorities, Greece, Spain

\section{Introduction}

Jurisdiction is defined as the capacity conferred by law on the institution to carry out a task, ie either to lay down rules of law (individual or impersonal) unilaterally or by contract, or to contribute to the laying down of such rules or to proceed in material energies. Responsibility is the subjective aspect of the operation and its specialization [4].

The content of local government is the administration of local affairs in a way that leads to sustainable local development, ie the promotion and service of local interests, in accordance with the constitution and the municipal and community code. A key element of local affairs is the promotion of the social, economic and ecological needs of the local communities, region and the satisfaction of basic needs of its inhabitants. Therefore, all local affairs are under the exclusive responsibility of local authorities.

The administration of all local affairs is the responsibility of municipalities and communities, whose main concern is the promotion of the social and economic interests, as well as the cultural and spiritual interests of its inhabitants [3].

\section{The Structure of Local Government in Greece}

The institution of local government is enshrined in the constitution of 1975 (article 102), which establishes the A 'and B' degree of local government [3]. Article 102 contains detailed provisions for the institution of local selfgovernment as follows:

1. The administration of local affairs belongs to the local authorities of first and second degree. In favor of the organizations there is a presumption of competence for the administration of local affairs. The law determines the scope and categories of local affairs, as well as their distribution into individual grades. By law it can be assigned to the local authorities the exercise of responsibilities, which constitute a mission of the state.

2. Local authorities have administrative and financial autonomy. Their principles are elected by universal and secret ballot, as required by law.

3. By law they may be provided for the execution of projects or the provision of services or the exercise of responsibilities of the local authorities compulsory or voluntary links, administered by elected bodies. 
4. The state exercises in the local authorities supervision, which consists solely of a review of legality and must not impede their initiative and free action. The review of legality is exercised as provided by law. Disciplinary penalties in the elected bodies of the local authorities, except in cases that automatically involve a reduction or holiday, are imposed only after the consent of a council, which consists by a majority of ordinary judges, as provided by law.

5. The State shall take the legislative, regulatory and budgetary measures required to ensure the financial independence and resources, which are necessary for the fulfillment of the mission and the exercise of the responsibilities of the local authorities while ensuring transparency in the management of these resources. The law defines the matters related to the return and distribution, among the local authorities, of the taxes or fees, which are determined in their favor and are collected by the state. Any transfer of responsibilities from central or regional bodies of the state to the local government implies the transfer of the respective resources. The law stipulates the matters related to the determination and collection of local revenues directly by the local authorities.

Following the provisions of the constitution, the concept of local self-government emerges as follows: Local selfgovernment is the independent (with own responsibility) exercise of local public administration by a territorial legal entity under public law with the partnership of all its members (people) and under the supervision of the state [4]. From this definition emerge essential conceptual elements of local self-government, such as: the existence of local selfgovernment bodies as territorial legal entities under public law, the direct election of their bodies, the autonomy of local authorities, state supervision and management of local affairs which is its essence.

The authorities of the local self-government organizations are elected by universal and secret ballot every four years, in order to express the popular sovereignty. Compulsory or voluntary associations of local government organizations, governed by a council with elected representatives of each municipality or community, which are taken in proportion to their population, may also be provided by law for the execution of projects or the provision of services. The law may provide for the participation in the administration of the local self-government organizations of the second degree of elected representatives of local professional, scientific and intellectual organizations and the state administration up to one third of the total number of members [12].

The municipality together with the local unit constitutes the first degree of local self-government. It consists of a clearly defined area and its population and usually refers to a city, town, village or a small grouping of them [18]. Local government is a form of regional decentralization, in which the central government transfers limited political and administrative power to a regional or local body. It aims to create opportunities for active citizen participation in the public and to strengthen the citizen's sense of responsibility and duty to society. In the competence of the local authorities local affairs belong. A local case is the one that refers to the promotion of the interests of the inhabitants of the region of local authorities. The Municipal and Community Code enumerates, as an indication, certain responsibilities that belong to the exclusive competence of the local authorities [4], such as the construction, maintenance and improvement of public municipal areas (roads, parks, squares, etc.), cleanliness and waste collection, maintenance of school buildings, management of municipal enterprises, the construction and maintenance of nurseries and hospitals, etc.

\section{The Structure of Local Government in Spain}

In Spain, there are three levels of government with 17 autonomous communities, 50 provinces and 8,111 municipalities. The country also owns two "autonomous" cities in North Africa, Ceuta and Melila [9-15].

The average population of primary Spanish local authorities amounts to 5,430 inhabitants, while $85 \%$ of the municipalities have a population of less than 5,000 inhabitants. Local authorities of Spain are represented by the Spanish Federation of Municipalities and Provinces, which represents 6,900 municipalities [15].

\section{The Legislative Framework of Local Government in Greece}

Local government is an autonomous administration, independent of the state with the main purpose of managing local common affairs by a representative body of the local community, in the establishment and ensuring of which the state supervision aims. Local governments are not state bodies, but the Constitution makes them private, ie recognizes them as subjects of rights and obligations and gives them administrative and financial independence. This means that they act within the framework of laws freely without being subject to the orders of state bodies or any other body of public power and their activities arise from the organizations themselves and not from the central bodies [4] To achieve cultural-political recognition for some regions and democracy for all the Spanish model of decentralisation was originally devised.

Independence can be distinguished in the organicadministrative, ie the right to take and execute decisions with their own bodies, the personal one which includes the right to elect the governing authorities and appointment, promotion and dismissal of key employees and the fiscal one which is financial independence of the local organization (property, revenues, expenses). In addition, the assignment of the administration of local affairs to the local authorities does not automatically mean the assignment of powers to issue the relevant regulations or to impose and collect taxes and fees. The above acts presuppose the issuance of a special 
legislative authorization, according to article 43 , par. 1 of the Constitution. Therefore, the Constitution guarantees the selfgovernment of the local authorities, but not their autonomy. The state exercises administrative supervision over the local authorities in a way, however, that does not hinder their initiative and free action, ie it exercises control of the legality of the acts of their local competence and not control of expediency [18].

\section{The Legislative Framework of Local Government in Spain}

In 1978, Spain was one of the most centralized countries in Europe. With the fear of division and the danger of secession, a decentralized state with many features of a federal organization was created. A special effort has been made to equip the autonomous communities with responsibilities and powers in such a way as to shield their legislative and executive autonomy. The debate over decentralization in Spain is ongoing. Many autonomous communities claim additional autonomy. An important body is the meeting of presidents, in which the prime minister and the presidents of the autonomous communities participate and concerns issues of national interest [1-17]. To achieve cultural-political recognition for some regions and democracy for all the Spanish model of decentralisation was originally devised. The Spanish system model of regional government according to some political scientists, has become increasingly president with style [14]. Regions have obtained the capacity to implement innovative policy solutions both in substantive and operational terms and ending in increasing policy diversity across ACs in areas as social services, environmental policy, education and health [10].

Spanish municipalities are subject to a posteriori legality review by state inspectors and the body of regional inspectors. In autonomous communities, where there are no bodies of inspectors, the audit is done directly by the audit committee. Local authorities transmit to the administrations of the state and the autonomous communities, within a period of six (6) days, a copy in which, if there is a case, an excerpt explaining the actions and decisions that have been taken. When the administration of the state or the autonomous communities deems, within the limits of their respective responsibilities, that an act or a decision of any local authority is contrary to the legal order may ask him to annul the specific act or decision. This must be stated within 15 working days of notification of the decision. If an local authority acts or takes decisions which seriously affect the general interest of Spain, the representative of the government has the right to suspend their application and to take the necessary measures to protect that interest. An appeal must be lodged within six (6) days of the suspension before the administrative court. There is no expediency check in the Spanish local authorities [6-8]. The structure of departments within regional administrations has been affected from the need to adapt to European Union (EU) policies and the emergence of coalition governments in many regions [7].

\section{Similarities and Differences}

In article 75 of Law 3463/2006, for the first time a thematic systematization of the responsibilities of the local authorities took place. The municipal and the community authorities manage and regulate all local affairs, in accordance with the principles of subsidiarity and proximity, with the aim of protecting, developing and continuously improving the interests and quality of life of the local community. The responsibilities of the municipalities and communities concern, mainly the sectors: a) Development b) Environment c) Quality of life and Well-functioning of cities and settlements d) Employment e) Social Protection and Solidarity f) Education, culture and sports g) Civil protection.

Municipalities and communities also exercise, at the local level, state responsibilities, which have been assigned to them in order to better serve the citizens, in accordance with the relevant legislation. Basic principles that must be taken into account and observed when allocating and exercising responsibilities are the principle of subsidiarity and the principle of proximity [12].

A very important peculiarity in the distribution of the responsibilities of the Spanish primary local authorities is that it is affected by their population size. All municipalities are responsible for the management of water supply, sewerage, municipal electricity, municipal road construction as well as the municipal police. Municipalities with a population of more than 5,000 have additional responsibilities for markets, public parks and libraries, while municipalities with a population of more than 20,000, in addition to the above responsibilities, also provide emergency and fire, social and welfare services, but and services related to sports infrastructure. Finally, municipalities with a population of more than 50,000 have the additional responsibilities, environmental protection and public transport. It is at the discretion of the municipalities to exercise responsibilities related to public safety, traffic management, cultural and tourist activities. The central state as well as the autonomous communities have the possibility to transfer, by concession, some of their responsibilities to the municipalities. One such responsibility, common to almost all municipalities, is the implementation of investment and operational programs in the field of education [17].

The local authorities have a limited stake in the provision of health services in Spain. It is mainly found in the protection of public health, slaughterhouses and participation in the administration of primary health centers. It is quite interesting that the respective Central Union has developed a very active movement, which demands more responsibilities and participation of municipalities in the provision of health services. All municipalities have responsibilities related to social welfare, social development and social reintegration. According to the law of local authorities for municipalities with a population of over 20,000 inhabitants, these 
responsibilities are mandatory.

Social housing is a responsibility mainly of the regions. Municipalities play a complementary role mainly in terms of control and protection against urban planning violations. They also have an indirect role in the establishment of general urban plans and rules in the construction of buildings. In recent years, many municipalities have started to create municipal legal entities with the object of social housing [5].

All levels of government are involved in employment policy. The central state is responsible for the institutional status and coordination of financial planning. Regions are responsible for regional planning and regional development, while municipalities are involved in retaining jobs, especially in declining or deindustrialized areas, setting up local employment offices, as well as, to a significant extent, supporting innovative business initiatives and their connection to the local labor market [5].

One of the characteristics of the regionalization of local authorities is that it administratively and financially limits the second degree of local authorities and sometimes removes it. The simplification of the administration and self-government systems in each country and the clear division of responsibilities between the state and the self-government are the main argument in Spain and similar measures have been taken, while in Greece the prefectural self-government has been transformed into a regional one.

The austerity policies implemented by the European states to deal with the financial crisis, created many problems in the local authorities, mainly in the amount of income and their staff (number, wages, employment status). This situation has worsened with the decentralization of responsibilities that is being implemented in several countries. The municipalities found themselves in the awkward position of trying to ensure an acceptable level of services with reduced resources as in the case of Greece and Spain.

It is clear that the revenues of the local authorities in most European countries have declined and this has adversely affected both their independence and their financial ability to respond to the provision of local municipal services. In this context, the aim is to increase the share of their own revenues in relation to government subsidies, in order to reduce dependence on the central government [13].

This reduction was accompanied by a reduction of operating expenses and mainly of the salary costs of the local authorities in most European countries. These trends have been accompanied by radical reorganizations of local authorities, especially in Spain where special emphasis has been placed on improving efficiency, adopting innovations and reducing costs. In addition, reductions in the number of staff were imposed in Greece. Finally, another impact concerns the reductions in the salaries of the elected, mainly both in Greece and in Spain [13].

Another attempt was made to privatize the municipalities. The main positive argument for the effectiveness of privatizations is that they promote competition and thereby save resources. Research conducted in the field of waste management in Spain and other European countries has found empirical evidence to suggest the creation of a centralized market. The existence of a high concentration implies the dominance of large private contractors, mainly in large municipalities, but also the development of local monopolies in the smaller ones. The high levels of centralization in the market imply higher costs for the provision of local services. A market with such a structure harms the conditions of competition, as there cannot be a sufficient number of contractors capable of bidding in all municipalities. A second key argument in favor of privatization is the effort to create and exploit economies of scale. But economies of scale cannot be achieved by privatization alone. In many European countries, such as Spain, local authorities have the opportunity to work with neighboring municipalities through inter-municipal cooperation schemes. These partnerships unify the provision of local services in a significant number of different municipalities [2].

In Greece, too, there are good practices for implementing inter-municipal cooperation in garbage collection. The municipalities of Karditsa and Plastira created a program of inter-municipal cooperation through THESEA. In this way they secured the logistical infrastructure, while the distribution of operating costs is done by objective criteria, such as itineraries, distances, volume, etc. The participating municipalities appear satisfied with this cooperation. In small municipalities, two are the main factors used to explain why the privatization of services does not yield the projected savings. In the first phase, the municipalities are likely to face difficulties in covering the high management costs (legal, financial, technical support) caused by the control of contracts with private companies. At the same time, it is possible that the number of contractors bidding will be limited and therefore, instead of competing, a local trust will be formed, which will manipulate prices and end up not saving costs [11].

\section{Conclusions}

Most European countries have addressed problems due to the fragmentation of the local authorities in many small units, with the aim of enhancing the effectiveness of spatial and development planning structures, processes and policies. Countries such as Greece and Spain have entered into forced or voluntary mergers of neighboring municipalities and communities, as well as (or alternatively) the deepening of inter-municipal cooperation institutions through the establishment of links and the conclusion of inter-municipal contracts for the provision of services and construction of projects. The forms of inter-municipal cooperation differ between countries and responsibilities of the local authorities. In addition to the forced or voluntary unions, in the large urban centers the reform initiatives concern the institutionalization of new forms of metropolitan administration or local government, through the creation of mixed forms of metropolitan government with the participation of local, economic and social bodies. 


\section{References}

[1] Agranoff, R. (2007). Spanish regions gain power. Federations, Oct, 19-21.

[2] Bel, G., \& Costas, A. (2006). Do public sector reforms get rusty? Local privatization in Spain. The Journal of Policy Reform, 9 (1), 1-24.

[3] Besila-Vika, E. (1995). The constitutional framework of the institution of local self-government. Athens: Sakkoula.

[4] Besila-Vika, E. (2004). Local government. Institutional framework - European dimension. Athens: Sakkoula.

[5] Broto, V. C., \& Dewberry, E. (2016). Economic crisis and social learning for the provision of public services in two Spanish municipalities. Journal of Cleaner Production, 112, 3018-3027.

[6] De Mello, L., \& Lago-Peñas, S. (2013). Local government cooperation for joint provision: the experiences of Brazil and Spain with inter-municipal consortia. The challenge of local government size. theoretical perspectives, international experience, and policy reform. Edward Elgar, Cheltenham, 221-241.

[7] Dudek, C. M. (2005) EU accession and Spanish regional development: Winners and losers, Brussels: Peter Lang.

[8] García-Sánchez, I. M., Frías-Aceituno, J. V., \& RodríguezDomínguez, L. (2013). Determinants of corporate social disclosure in Spanish local governments. Journal of Cleaner Production, 39, 60-72.

[9] Gold, P. (2000). Europe or Africa? A contemporary study of the Spanish North African enclaves of Ceuta and Melilla. Oxford University Press.

[10] Gallego, R., Gomà, R. and Subirats, J. (2005) 'Spain, from state welfare to regional welfare?', in N. McEwen and L. Moreno (eds) The territorial politics of welfare, London: Routledge.

[11] Karanikola, P., \& Tampakis, S. (2008). Domestic waste management as a means for life quality improvement and environmental protection in the city of karditsa: citizens'viewpoint. International Journal of Sustainable Development and Planning, 3 (1), 73-82.

[12] KEDE (2017). Tax decentralization \& enhancement of the financial independence of the first degree local authorities in Greece. Athens.

[13] Knieling, J., \& Othengrafen, F. (2015). Cities in crisis: Sociospatial impacts of the economic crisis in Southern European cities. Routledge.

[14] Magone, J. M. (2004). Contemporary Spanish politics, London/New York: Routledge.

[15] Medina, Y. F., De Miguel, E. O., \& Rodríguez, J. J. S. (2012). Tendencias actuales en las tecnologías de tratamiento de las aguas residuales generadas en las pequeñas aglomeraciones urbanas. Ingeniería civil, (168), 131-143.

[16] Ruano, J. M. (2017). Functional federalism in a complex state: The case of Spain. In The Palgrave Handbook of Decentralisation in Europe (pp. 77-101). Palgrave Macmillan, Cham.

[17] Ruano, J. M., \& Álvarez, J. M. R. (2016). Local structure and municipal associations in Spain: Facts, trends and problems. In Comparative Studies and Regionally-Focused Cases Examining Local Governments (pp. 71-90). IGI Global.

[18] Zygouris, P. \& Papadopoulos, G. (2010). Kallikratis Program. Athens: Olgas Zygouri Publications. 